\title{
Biological Effects of the Leaves and Roots of Ligularia stenocephala
}

\author{
Young-Joo Nam and Dong-Ung Lee*
}

Division of Bioscience, Dongguk University, Gyeongju 780-714, Korea

Received October 4, 2013 /Revised November 4, 2013 /Accepted November 5, 2013

\begin{abstract}
The leaves and roots of Ligularia stenocephala, which are widely used as a food in Korea, were investigated for their antioxidant activities and cytotoxicity in vitro, and their hepatoprotective effect, alcohol detoxicant efficacy, and memory-enhancing property were investigated in vivo. The unique odor of the leaves was analyzed by GC-MS. Lipid peroxidation, superoxide anion formation, and DPPH radicals were inhibited remarkably by the extracts of the leaves and roots. The leaves of this edible plant significantly protected the hepatotoxicity induced by carbon tetrachloride and further diminished the blood alcohol content in mice. While the roots of this plant exhibited adequate cytotoxicity against four human tumor cell lines, especially against melanoma, the leaves revealed relatively weak activity. Both the leaves and the roots exerted an excellent ameliorating property on scopolamine-induced memory impairment in the passive avoidance task using an animal model. The hexane fraction of the leaves was analyzed by GC-MS, suggesting that a series of terpenoids may be odorous compounds in this plant.
\end{abstract}

Key words : Antioxidant, cytotoxicity, hepatoprotection, Ligularia stenocephala, memory

\section{서 론}

곤달비(Ligularia stenocephala)는 국화과의 다년초로서 높이 는 60-100 cm이며 꽃은 8-9월에 피고 우리나라 전국의 심산지 역에서 자란다. 어린잎은 식용하고 굵은 근경 끝에 잔뿌리가 있어 사방으로 퍼져 있다. 곤달비는 관상 및 식용자원으로서 가치가 높은 생물자원이며 독특한 향을 가지고 있고, 식용으 로 사용하기 위하여 하우스 재배를 하고 있으나 대량 재배가 쉽지 않아 공급이 부족한 실정이다. 곤달비와 비슷한 생김새 와 식품으로서의 용도를 가진 동속 식물인 곰취(Ligularia fischeri)는 곤달비에 비해서 잎은 밑이 창 모양이 아니라 심장 모양이며, 잎 끝이 갑자기 뾰족해지지 않고, 혀모양꽃은 5-9개 로서 많으므로 구분된다.

곤달비의 효능에 관한 연구보고는 잎에 대한 연구가 대부분 이며 잎의 물추출물 및 용매분획의 $\mathrm{DPPH}$ 및 $\mathrm{ABTS}$ 라디칼 소거 활성[4], in vitro와 in vivo에서의 암전이 억제 효과[7], 메탄올 추출물의 항비만 효과[12], 궤양크기 및 소화액 분비 감소에 의한 소화기 궤양 억제효과[6], 혈소판응집 억제 및 항 혈액응고 효과[23] 등이 있으나 아직 본 연구와 관련하여 간보 호 및 알코올 분해 효과, 세포독성, $\mathrm{DPPH}$ 소거효과를 제외한 항산화 활성, 기억증진 효과등은 보고되지 않았다. 더욱이 잎

\section{*Corresponding author}

Tel : +82-54-770-2224, Fax : +82-54-742-9833

E-mail : dulee@dongguk.ac.kr

This is an Open-Access article distributed under the terms of the Creative Commons Attribution Non-Commercial License (http://creativecommons.org/licenses/by-nc/3.0) which permits unrestricted non-commercial use, distribution, and reproduction in any medium, provided the original work is properly cited.
과 뿌리의 생물활성을 비교 검토한 연구는 없으며 영양 성분 의 종류와 함량에 대해서 곤달비 잎을 13 종의 산채와 함께 비교한 연구결과[5]가 있는데 이 보고에서 곤달비는 특히 다른 산채에 비해 배당체의 함량이 가장 많은 것으로 밝혀졌다. 곤달비의 성분으로는 sesquiterpenes [22], triterpenes [20], phenolics [17], benzofuran derivatives [15, 18, 10, 21, 19], 기 타 다양한 구조의 화합물 $[8,16]$ 들이 보고되어 있으나 곤달비 향기의 성분 중의 하나인 monoterpene에 대해서는 아직 알려 져 있지 않다.

본 연구에서는 독특한 향과 맛을 지닌 산나물로 애용되고 있는 곤달비의 생물활성을 탐색하기 위하여 아직 보고되지 않은 효과를 중심으로 in vitro와 in vivo에서 평가하였으며 향 기성분을 분석하여 새로운 성분을 확인하였다.

\section{재료 및 방법}

\section{실험재료 및 기기}

실험재료 식물인 곤달비는 경주시 산내면 산내농업협동조 합에서 제공받았다. 효능시험에 사용된 모든 시약은 Sigma사 (St. Louis, MO, USA) 제품을 사용하였으며 유기용매 및 무기 시약들은 국산특급을 사용하였다. 실험동물은 대한바이오링 크(충북)에서 구입한 외관상 건강한 ICR계 웅성 mouse ( $30 \pm 1$ $\mathrm{g}$ )를 본 대학 동물사육실에서 일정한 조건으로 사육하여 실험 에 사용하였다. 사육조건은 온도는 $22 \pm 1^{\circ} \mathrm{C}$, 습도는 $55 \pm 5 \%$ 그 리고 명암은 12시간 light/dark cycle을 유지시켰다. 실험동물 을 1 주일간 사육실에서 적응시켰으며 실험개시 전 24 시간 동 안 물만 먹이고 절식시켰다. 동물처치는 효소활성의 일중변동 을 고려하여 오전 10-12시 사이에 실시하였다. 수동회피시험 
(Passive avoidance task) 기기는 Gemini Avoidance System (San Diego Instruments, San Diego, CA, USA)을 이용하였고, 성분분석을 위한 GC-MS 기기는 Agillent 5975 C를 이용하였 다.

\section{추출물 제조}

곤달비 잎과 뿌리를 잘 건조하여 분말로 만든 다음, 각 600 $\mathrm{g}$ 을 메탄올 21 로 2 시간 가온 추출하였다. 추출액을 감압 농축 하여 용매를 완전 제거하고 냉동건조기로 추출물 시료를 제조 하였다. 잎과 뿌리 추출물의 수득율은 각각 $10.25 \%$ 와 $15.79 \%$ 이었다. 잎의 향기성분을 분석하기 위하여 건조된 잎 분말 50 $\mathrm{g}$ 에 $n$-헥산 $100 \mathrm{ml}$ 을 넣고 2일간 실온에 방치한 다음, 용매를 제거하고 분석시료로 하였다.

\section{지질과산화 억제 활성}

Ohkawa 방법[13]에 따라 다음과 같이 과산화지질의 함량 을 측정하였다. 먼저 $0.1 \mathrm{M}$ potassium phosphate 완충액 $(\mathrm{pH}$ $7.4) 0.65 \mathrm{ml}$, 시료 $0.05 \mathrm{ml}$ (농도 $1.0 \mathrm{mg} / \mathrm{ml}, 2.0 \mathrm{mg} / \mathrm{ml}, 4.0$ $\mathrm{mg} / \mathrm{ml}$ ), homogenate $0.1 \mathrm{ml}$ 을 $37^{\circ} \mathrm{C}$ 에서 1 시간 동안 incubation 하였다. 1시간 후 반응액에 8.1\% SDS $0.2 \mathrm{ml}$, acetate 완충액 $(\mathrm{pH} 3.5) 1.5 \mathrm{ml}, 0.8 \%$ 2-thiobarbituric acid $1.5 \mathrm{ml}$ 을 첨가하고, $95^{\circ} \mathrm{C}$ 에서 1 시간 반응시킨 다음 실온으로 냉각하였 다. 이 반응액에 $n$ 부탄올: pyridine $15: 1$ (v/v) $5 \mathrm{ml}$ 을 첨가하 여 $3,000 \mathrm{rpm}$ 에서 10 분간 원심분리한 후 상징액을 취하여 532 $\mathrm{nm}$ 에서 흡광도를 측정하였다. 양성 대조물질은 a-tocopherol (vitamin E)을 사용하였으며 시료 대신 DMSO를 가하여 반응 시킨 용액을 대조군으로 하여 저해율(\%)을 계산하였다.

\section{Superoxide anion 억제 활성}

Gotoh 등의 방법[3]을 일부 변형하여 다음과 같은 방법으로 측정하였다. 먼저 $1.0 \mathrm{mg} / \mathrm{ml}, 2.0 \mathrm{mg} / \mathrm{ml}, 4.0 \mathrm{mg} / \mathrm{ml}$ 농도의 시료 $30 \mu \mathrm{l}$ 에 $30 \mathrm{mM}$ EDTA (pH 7.4) $100 \mu \mathrm{l}, 30 \mathrm{mM}$ hypoxanthine $10 \mu \mathrm{l}, 1.42 \mathrm{mM}$ NBT $200 \mu \mathrm{l}$ 를 가한 다음 실온에서 3 분 반응시킨 후, $0.5 \mathrm{U} / \mathrm{ml}$ xanthine oxidase $100 \mu 1$ 를 첨가하 고 $50 \mathrm{mM}$ phosphate 완충액( $\mathrm{pH}$ 7.4)으로 총 용량을 $3 \mathrm{ml}$ 로 맞추고 반응용액을 실온에서 20 분간 반응시킨 후, $560 \mathrm{~nm}$ 파 장에서 흡광도를 측정하였다. 양성대조물질은 ascorbic acid (vitamin C)를 사용하였으며 시료 대신 DMSO를 가하여 반응 시킨 용액을 대조군으로 하여 저해율(\%)을 산출하였다.

\section{DPPH radical 소거 활성}

Blois 방법[2]을 사용하여 다음과 같이 측정하였다. 즉 1.0 $\mathrm{mg} / \mathrm{ml}, 2.0 \mathrm{mg} / \mathrm{ml}, 4.0 \mathrm{mg} / \mathrm{ml}$ 농도의 각 시료 $0.1 \mathrm{ml}$ 에 $\mathrm{DPPH}$ 라디칼 $1.5 \times 10^{-5} \mathrm{M}$ 에탄올 용액 $4 \mathrm{ml}$ 을 첨가하여 실온 에서 30 분간 반응시킨 후, $520 \mathrm{~nm}$ 에서 흡광도를 측정하였다. 소거효과는 다음 식에 의해 \%로 산출하였다.
Radical scavenging activity $(\%)=\left\{\left(\mathrm{OD}_{\text {control }}-\mathrm{OD}_{\text {sample }}\right) /\right.$ $\mathrm{OD}_{\text {control }} \times 100$

\section{간보호 효과}

실험동물은 ICR mouse (6주령, 수컷) 8 마리씩을 1 개군으로 나누어 실험하였다. 실험군은 각각의 시료를 $500 \mathrm{mg} / \mathrm{kg}$ 으로 하여 $\mathrm{DMSO}$ 에 녹여 6일간 경구투여하였으며 3일 간격으로 시료투여 30 분 후 $25 \% \mathrm{CCl}_{4}$ 의 olive oil을 $4 \mathrm{ml} / \mathrm{kg}$ 용량으로 경구투여하였다. 대조군은 6 일간 정상사육 중 3 일 간격으로 $25 \% \mathrm{CCl}_{4}$ 의 olive oil을 $4 \mathrm{ml} / \mathrm{kg}$ 으로 경구투여하였으며 마지 막 투여 24시간 후 마취상태에서 혈액을 채취하였다. 정상군 도 같은 시간에 마취하여 채혈하였으며 혈중 AST와 ALT의 활성은 Sigma사(St. Louis, MO, USA) kit (MAK055, MAK052) 를 사용하였다.

\section{알코올 분해 효과}

알코올 분해효과는 알코올 투여 후 혈중 알코올의 함량을 측정하는 방법을 사용하였다. ICR mouse (6주령, 수컷) 9 마리 씩 군을 나누어 실험군은 각 시료를 $10 \mathrm{ml} / \mathrm{kg}$ 의 양으로 만들 어 $0.1 \mathrm{ml}$ 를 1 회 경구투여 하였으며 대조군은 증류수를 0.1 $\mathrm{ml} 1$ 회 경구투여하였다. 시료투여 30 분 후 $40 \%$ 에탄올 0.1 $\mathrm{ml}$ 을 1회 경구투여하고 투여 한시간 후에 혈액을 채취하였으 며, 혈중 알코올 농도는 전문검사기관인 의료법인 삼광의료재 단(서울)에 의뢰하여 측정하였다.

\section{세포독성}

세포배양은 온도 $37^{\circ} \mathrm{C}$, 습도 $100 \%, \mathrm{CO}_{2}$ 농도 $10 \%$ 를 유지하 였다. 시료투여 전일 24-well plate에 혈청 10\% D-MEM을 각 well 마다 $1.0 \mathrm{ml}$ 씩 넣은 다음, 배양중의 세포를 trypsin 처리 하여 수확하여 cell counter로 세포농도를 계산하였다. D$\mathrm{MEM}$ 으로 농도별로 희석하여 세포수를 달리하여 각각의 well 에 plating 하였다. 시료의 투여는 cell plating 18시간 후, medium을 흡인하여 버린 후, serum-free D-MEM을 well당 1.0 $\mathrm{ml}$ 씩 넣고 시료를 serum-free D-MEM으로 농도별로 희석하 여 각 well에 투여하였다. 투여 4시간 후, medium을 모두 제거 한 뒤, 다시 serum $10 \% \mathrm{D}-\mathrm{MEM}$ 을 well당 $2.0 \mathrm{ml}$ 씩 넣었다. 시료투여 6일 후, medium을 모두 제거하고 crystal violet으로 3 분간 염색하여 건조시킨 후, 해부현미경으로 관찰, colony수 를 파악하고 plating한 cell의 수와 비교하여 생존율을 계산하 였다. 사용한 암세포는 한국화학연구원에서 배양중인 세포주 를 사용하였으며 A549 (lung), SK-OV-3 (ovary), SK-MEL-2 (melanoma), HCT-15 (colon) 등 네 종류이다.

\section{기억증진 효과}

동물모델시험으로 수동회피시험(passive avoidance task) 을 실시하였다. 실험 장치는 두 개의 방으로 구성된 shuttle 
box의 가운데에 guillotine door가 있으며 한쪽 방에는 바닥 전체에 전기쇼크를 가할 수 있는 장치가 되어 있다. 전체 실험 은 컴퓨터로 제어할 수 있도록 되어 있으며 실험동물이 전기 쇼크실에 들어가는 시간을 자동 측정하여 data화 한다. 먼저, training trial에서, 실험동물인 ICR mouse (6주령)에 곤달비 뿌리 및 잎의 메탄올 추출물 각 $250 \mathrm{mg} / \mathrm{kg}$ 및 tacrine (양성대 조약물) $2.5 \mathrm{mg} / \mathrm{kg}$ 을 $30 \% \mathrm{DMSO}$ 에 녹여 $0.1 \mathrm{ml}$ 씩 7일간 경구투여하였고 마지막 투여 1시간 후 기억상실약물인 scopolamine $1.0 \mathrm{mg} / \mathrm{kg}$ 을 복강 주사하고 30 분 후에 회피시험을 실시하였다. 회피시험은 실험군 또는 대조군 각 1 마리씩 한쪽 방에 넣고 15 초간의 탐색시간을 준 뒤, 위에서 조명과 소음을 가하면 가운데의 guillotine door를 통과하여 조용하고 어두운 다른 방(쇼크실)에 도달한다. 쥐가 쇼크실에 들어가면 자동적 으로 guillotine door가 닫히면서 전기쇼크가 가해진다. 쇼크 는 $0.3 \mathrm{~mA}$ 의 전류를 3 초간 통하게 하였으며 쥐가 foot-shock 를 받은 후에 꺼내어 home cage에 다시 넣어둔다. 이러한 방법 으로 각각 7-10마리의 실험군과 대조군에 대하여 전기쇼크를 가하였으며 120 초 동안에 쇼크실로 들어가지 않는 쥐는 실험 대상에서 제외시켰다. 다음으로 retention trial은 24시간 후, 위의 training을 받은 쥐에 대해 전기쇼크를 실시했을 때, 약물 의 기억증진효과가 있으면 쥐가 전날의 쇼크를 기억하여 쇼크 실로 잘 들어가지 않게 된다. 따라서 쇼크실로 들어가는 시간 이 길수록 수동회피의 학습과 기억효과가 좋음을 나타낸다. 이 때, 쇼크실 도달시간(step-through latency time)은 300초 (cut-off time)까지 측정하였다.

\section{향기성분 추출 및 분석}

곤달비 잎 시료 $1 \mathrm{~g}$ 에 $n$ 헥산 $20 \mathrm{ml}$ 을 넣고 실온에서 48 시간 추출한 다음, 헥산을 증류하여 제거하고 추출액 $5.2 \mathrm{mg}$ 을 얻었 다. 이 추출액에 함유된 향기성분을 GC-MS법으로 분석하였 으며 분석조건은 다음과 같다. Column: HP5MS, Carrier gas: $\mathrm{He}(1 \mathrm{ml} / \mathrm{min})$, Split ratio: $20: 1$, Oven temperature: $80^{\circ} \mathrm{C}$ 에서 3 분간 holding한 다음, 이후 1 분당 $5^{\circ} \mathrm{C}$ 로 $300^{\circ} \mathrm{C}$ 까지 유지.

\section{통계 처리}

모든 실험결과는 통계분석프로그램인 Origin (Version 3.78)으로 처리하였으며 data는 mean \pm S.E. 로 표시하였고 통 계적 유의성은 Student's t-test로 검정하여 유의수준을 P value로 나타내었다.

\section{결과 및 고찰}

\section{지질과산화 억제 효과}

세포막을 구성하는 성분인 인지질의 불포화지방산은 활성 산소(reactive oxygen species)에 의해 지질과산화반응(lipid peroxidation; $\mathrm{LPO}$ )을 일으키며, 이때 생성된 과산화지질은 세포막 손상의 주요 원인이 되어 각종 조직에 손상을 가져오 는 것으로 최근 보고되고 있다[1]. 곤달비의 과산화지질 생성 억제효과를 측정한 결과(Table 1), 용량의존적으로 억제율이 높아졌는데, 낮은 용량 $(1 \mathrm{mg} / \mathrm{ml})$ 에서는 잎추출물 $(20.4 \%)$ 이 뿌리추출물에 비해 효과가 4 배 가량 높았으며, 높은 용량 $(4$ $\mathrm{mg} / \mathrm{ml}$ )에서는 뿌리추출물 $(59.1 \%)$ 이 잎추출물 보다 효과가 약간 더 좋은 것으로 나타났지만 전반적으로 볼 때, 곤달비 잎이 지질과산화 억제에 의한 항산화 활성이 좋은 것으로 평 가된다.

\section{Superoxide anion 억제 활성}

활성산소(reactive oxygen species)의 하나인 슈퍼옥시드 음 이온(superoxide anion)은 세포를 손상시키는 산소라디칼 중 의 하나이다. 일반적으로 산화적 스트레스(oxidative stress)가 발생되는 세포에서는 자체 내 방어기전(항산화 기전)을 가지 고 있는데, 라디칼의 형성 정도와 그것에 대한 방어기전의 불 균형에 의해 손상이 일어난다[9]. 이 활성산소의 생성을 억제 하는 효과는 잎추출물과 뿌리추출물에서 모두 용량의존적인 경향을 보였는데, 지질과산화 억제효과와는 달리 모든 용량에 서 뿌리추출물이 잎추출물보다 더 좋은 억제효과가 있는 것으 로 조사되었다(Table 1).

\section{$\mathrm{DPPH}$ 라디칼 소거 활성}

항산화 활성을 측정하는 또 다른 지표로서 $\mathrm{DPPH}$ 라디칼 소거효과를 관찰하였다. DPPH (1,1-diphenyl-2-picrylhydrazyl)는 비교적 안정한 라디칼로서 불안정한 라디칼인 $\mathrm{OH}$ (hydroxyl radical)나 ' ${ }^{\circ} \mathrm{O}_{2}$ (superoxide anion)와 달리 반응시 취급이 용이하므로 많이 이용되고 있다. 잎과 뿌리추출물 모 두 용량의존적으로 좋은 라디칼 소거활성을 보였는데, 낮은 용량 $(1 \mathrm{mg} / \mathrm{ml})$ 에서는 뿌리추출물이 잎추출물 보다 활성이 높 았으나 그 보다 높은 용량에서는 두 추출물 모두 비슷하게 뛰어난 활성(77-79\%)을 나타내었다(Table 1). Kim 등[4]은 곤 달비 잎추출물을 다시 몇 개의 분획물로 나누어 이 중에서

Table 1. Antioxidant activities of the leaves and roots of Ligularia stenocephala

\begin{tabular}{|c|c|c|c|c|c|c|c|c|c|}
\hline & \multicolumn{3}{|c|}{ LPO } & \multicolumn{3}{|c|}{ Superoxide anion } & \multicolumn{3}{|c|}{ DPPH } \\
\hline & $1 \mathrm{mg} / \mathrm{ml}$ & $2 \mathrm{mg} / \mathrm{ml}$ & $4 \mathrm{mg} / \mathrm{ml}$ & $1 \mathrm{mg} / \mathrm{ml}$ & $2 \mathrm{mg} / \mathrm{ml}$ & $4 \mathrm{mg} / \mathrm{ml}$ & $1 \mathrm{mg} / \mathrm{ml}$ & $2 \mathrm{mg} / \mathrm{ml}$ & $4 \mathrm{mg} / \mathrm{ml}$ \\
\hline Leaves & $20.4 \pm 8.60$ & $27.3 \pm 15.1$ & $51.1 \pm 4.38$ & $9.3 \pm 0.10$ & $15.4 \pm 0.77$ & $21.9 \pm 0.19$ & $54.2 \pm 7.58$ & $75.1 \pm 2.04$ & $76.9 \pm 1.25$ \\
\hline Roots & $5.3 \pm 1.22$ & $9.1 \pm 2.27$ & $59.1 \pm 5.68$ & $14.0 \pm 0.76$ & $20.2 \pm 0.20$ & $27.4 \pm 0.09$ & $72.2 \pm 4.64$ & $74.4 \pm 1.38$ & $78.8 \pm 2.35$ \\
\hline Vitamin C & $46.6 \pm 7.95$ & $83.0 \pm 3.40$ & - & $31.9 \pm 0.77$ & $51.3 \pm 0.48$ & - & $84.8 \pm 2.77$ & $98.9 \pm 0.89$ & - \\
\hline
\end{tabular}




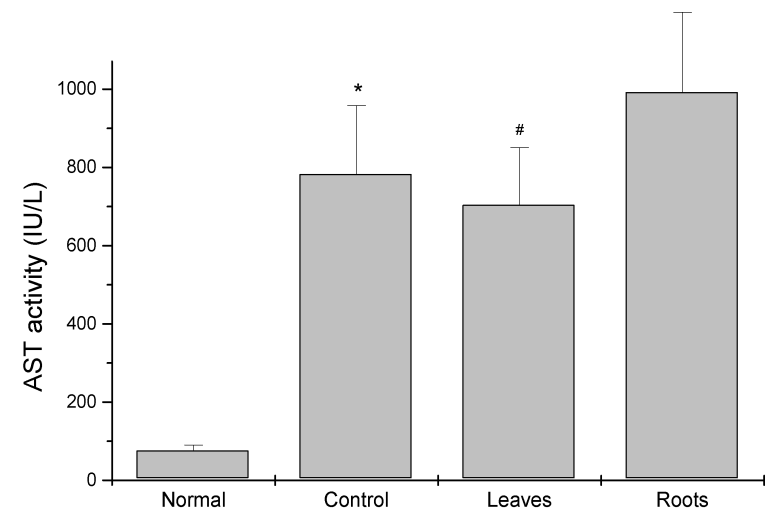

Fig. 1. Effect of the leaves and roots of Ligularia stenocephala on serum AST levels in $\mathrm{CCl}_{4}$-induced hepatotoxicity in mice. Data represent the mean \pm S.E $(n F 3)$. *: $p<0.05$ from normal, \#: $p<0.05$ from control.

ethylacetate 분획물이 강한 $\mathrm{DPPH}$ 라디칼 소거활성 $\left(\mathrm{IC}_{50}=0.28\right.$ $\mathrm{mg} / \mathrm{ml})$ 과 $\mathrm{ABTS}$ 라디칼 소거활성 $(0.5 \mathrm{mg} / \mathrm{ml}$ 농도에서 $96.67 \%)$ 이 있음을 보고한 바 있다.

\section{간보호 효과}

실험동물에 사염화탄소로 간독성을 유발시킨 다음, 시료를 투여하여 간독성이 어느 정도 회복되는지를 AST와 ALT 효소 활성을 지표로 조사하였다. Fig. 1에서 보는 바와 같이 대조군 은 간독성이 크게 유발되었음을 확인할 수 있으며, AST 효소 활성에서는 잎추출물이 대조군 보다 약 $10 \%$ 정도 낮아 효과가 있었으나 뿌리추출물은 오히려 활성도를 증가시켜 간독성이 개선되지 않은 것으로 나타났다. 이러한 경향은 ALT 효소활 성에서도 그대로 나타났는데 잎추출물이 대조군 보다 약 $78 \%$ 정도로 크게 낮아 효과가 매우 좋았으나 뿌리추출물은 오히려 활성도를 증가시켜 간독성이 개선되지 않은 것으로 나타났다 (Fig. 2). 즉, 곤달비 잎은 간보호 효과가 뛰어나지만 곤달비

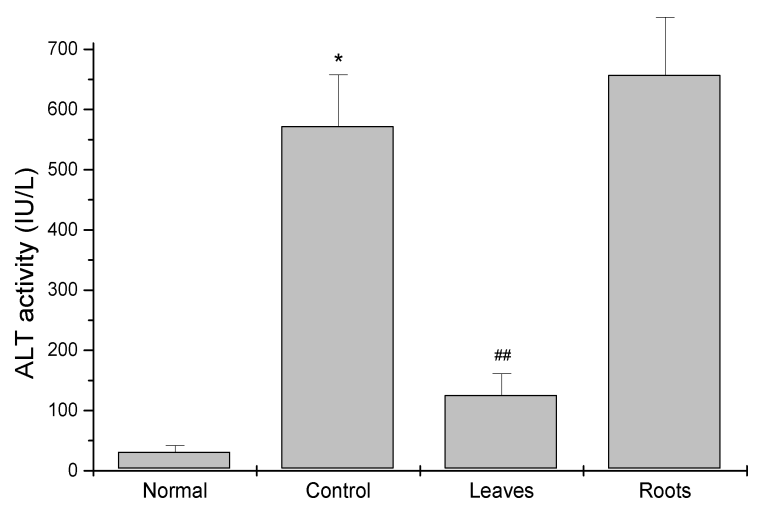

Fig. 2. Effect of the leaves and roots of Ligularia stenocephala on serum ALT levels in $\mathrm{CCl}_{4}$-induced hepatotoxicity in mice. Data represent the mean \pm S.E $(n=3)$. *: $p<0.05$ from normal, \#\#: $p<0.01$ from control.

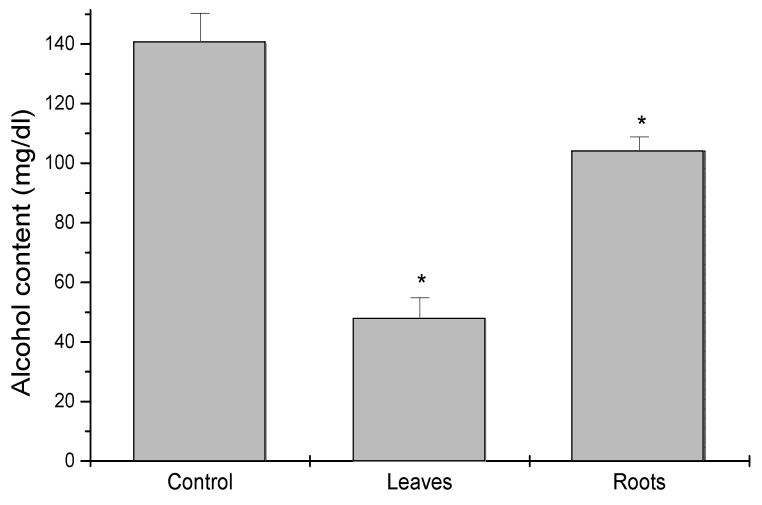

Fig. 3. Effect of blood alcohol content of the leaves and roots of Ligularia stenocephala. Data represent the mean \pm S.E. $(n=9) .{ }^{*}: p<0.05$ from control.

뿌리는 간독성개선에 아무런 효과가 없고 오히려 독성을 유발 하는 것으로 나타나 뿌리를 식용으로 사용하기 위해서는 주의 가 필요할 것으로 판단된다.

\section{알코올 분해 효과}

실험동물에 먼저 시료를 투여한 다음, 알코올을 경구투여하 고 1 시간 후에 혈중 알코올 농도를 측정한 결과, 잎과 뿌리 모두 알코올을 빨리 분해하는 효과가 있었는데, 특히 잎추출 물 투여 시 알코올 농도가 $47.50 \pm 7.29 \mathrm{mg} / \mathrm{dl}$ 로서 대조군 $(140.25 \pm 10.15 \mathrm{mg} / \mathrm{dl})$ 에 비해 $60 \%$ 감소되었다(Fig. 3). 따라서 잎추출물은 음주후의 알코올 분해에 효과적으로 사용할 수 있을 것으로 보인다. 한편, 뿌리추출물 투여 시에도 혈중 알코 올 농도가 $50 \%$ 감소하여 효과를 인정할 수 있었다.

\section{세포 독성}

잎추출물은 피부암인 흑색종에 효과 $\left(\mathrm{IC}_{50}=74.5 \mathrm{mg} / \mathrm{ml}\right)$ 가 있었으나 다른 암세포 억제효과는 비교적 약하였다. 곤달비 뿌리는 폐암, 난소암, 흑색종, 직장암의 네가지 암세포를 모두 효과적으로 억제하는 것으로 나타났는데 특히, 흑색종에 대한 효과가 강하였으며 $\left(\mathrm{IC}_{50}=40.1 \mathrm{mg} / \mathrm{ml}\right)$ 고농도인 $100 \mathrm{mg} / \mathrm{ml}$ 에 서는 암세포를 완전히 억제하였다. 다음으로는 직장암 세포에 대해 $\mathrm{IC}_{50}=52.6 \mathrm{mg} / \mathrm{ml}$ 로 비교적 좋은 세포독성을 나타내었다 (Table 2). Lee 등[7]은 곤달비 메탄올 추출물(부위 불명)이 흑 색종 암세포에서 $\mathrm{MMP}$ 효소들을 저해함으로서 암전이를 억 제함을 확인한 바 있으나 다양한 암세포에 대한 세포독성은 아직 보고되지 않았다.

Table 2. Cytotoxicity of the leaves and roots of Ligularia stenocephala

\begin{tabular}{lrccc}
\hline \multirow{2}{*}{ Part } & \multicolumn{4}{c}{$\mathrm{IC}_{50}(\mathrm{mg} / \mathrm{ml})$} \\
\cline { 2 - 5 } & A549 & SK-OV-3 & SK-MEL-2 & HCT15 \\
\hline Leaves & $>100.0$ & $>100.0$ & 74.51 & $>100.0$ \\
Roots & 76.49 & 59.34 & 40.14 & 52.63
\end{tabular}




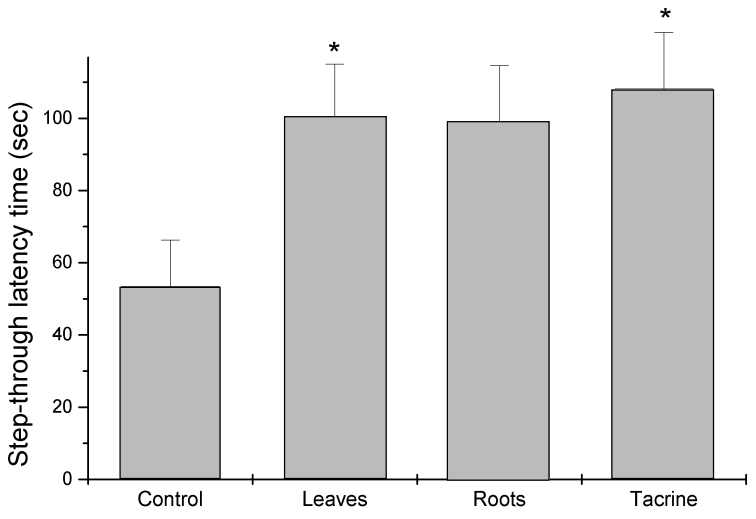

Fig. 4. Ameliorating effect of the leaves and roots of Ligularia stenocephala on scopolamine-induced amnesia in the passive avoidance task. Data represent the mean \pm S.E ( $n F 7)$. Tacrine was used as a reference compound (positive control).

\section{기억증진 효과}

실험동물에 scopolamine을 투여하여 기억을 상실시킨 다 음, 시료를 투여하여 기억이 회복되는 정도를 수동회피시험 (passive avoidance task)으로 관찰하였다. 이 시험법은 mouse 나 rat와 같은 작은 동물모델을 이용하여 단기 또는 장기기억 을 평가하는 fear-motivated test로 개발된 것이다[11]. Scopolamine은 무스카린성 길항제로서 학습습득이나 단기기 억을 손상시키기 때문에 항치매약물 검색에서 기억상실제로 사용된다[14]. 대조군의 회피시간(step-through latency time)
이 $53.5 \pm 12.8$ 초인데 비해서 곤달비 잎과 뿌리가 $250 \mathrm{mg} / \mathrm{kg}$ 에 서 각각 $100.5 \pm 14.5$ 초와 $98.8 \pm 15.8$ 초로 대조군 보다 기억력이 크게 증가하였다(Fig. 4). 양성대조약물인 tacrine은 $2.5 \mathrm{mg} / \mathrm{kg}$ 에서 회피시간이 $108.2 \pm 15.6$ 초로 우수하였으나 이 약물이 단 일 화합물임을 감안하면 곤달비 잎과 뿌리 추출물은 학습과 기억증진효과가 매우 좋은 효과로 판단된다. Tacrine은 효과 는 뛰어나나 신장독성이 강하여 현재 임상에서는 사용하지 못하고 이러한 실험의 표준약물로 사용되고 있다.

\section{향기성분 분석}

곤달비 잎의 향기성분(헥산 분획)을 GC-MS법으로 분석한 결과(Fig. 5), monoterpene인 $\beta$-phellandrene (4.38\%, Rt=5.54 $\mathrm{min})$, sesquiterpene인 caryophyllene $(2.44 \%, \mathrm{Rt}=15.31 \mathrm{~min})$ 과 a-farnesene $(0.61 \%, \mathrm{Rt}=17.44 \mathrm{~min})$ 이 검출되었으며 곤달비 잎의 독특한 향기는 주로 이들 성분에서 유래되는 것으로 추 정된다. 헥산 분획중에서 가장 큰 피크는 $\mathrm{Rt}=17.83 \mathrm{~min}$ 의 3-(1,5-dimethyl-4-hexenyl)-6-methylene-cyclohexene (7.82\%) 이고 그 다음으로 큰 $\mathrm{Rt}=24.39 \mathrm{~min}$ 의 피크는 미지 화합물의 피크이며 $\mathrm{Rt}=41.2 \mathrm{~min}$ 의 피크는 squalene $(4.78 \%)$ 인 것으로 확인되었다.

\section{감사의 글}

본 연구는 산내농업협동조합(경주)과 동국대학교 경주캠퍼 스의 연구비 지원에 의해 이루어졌으며 이에 감사드립니다.

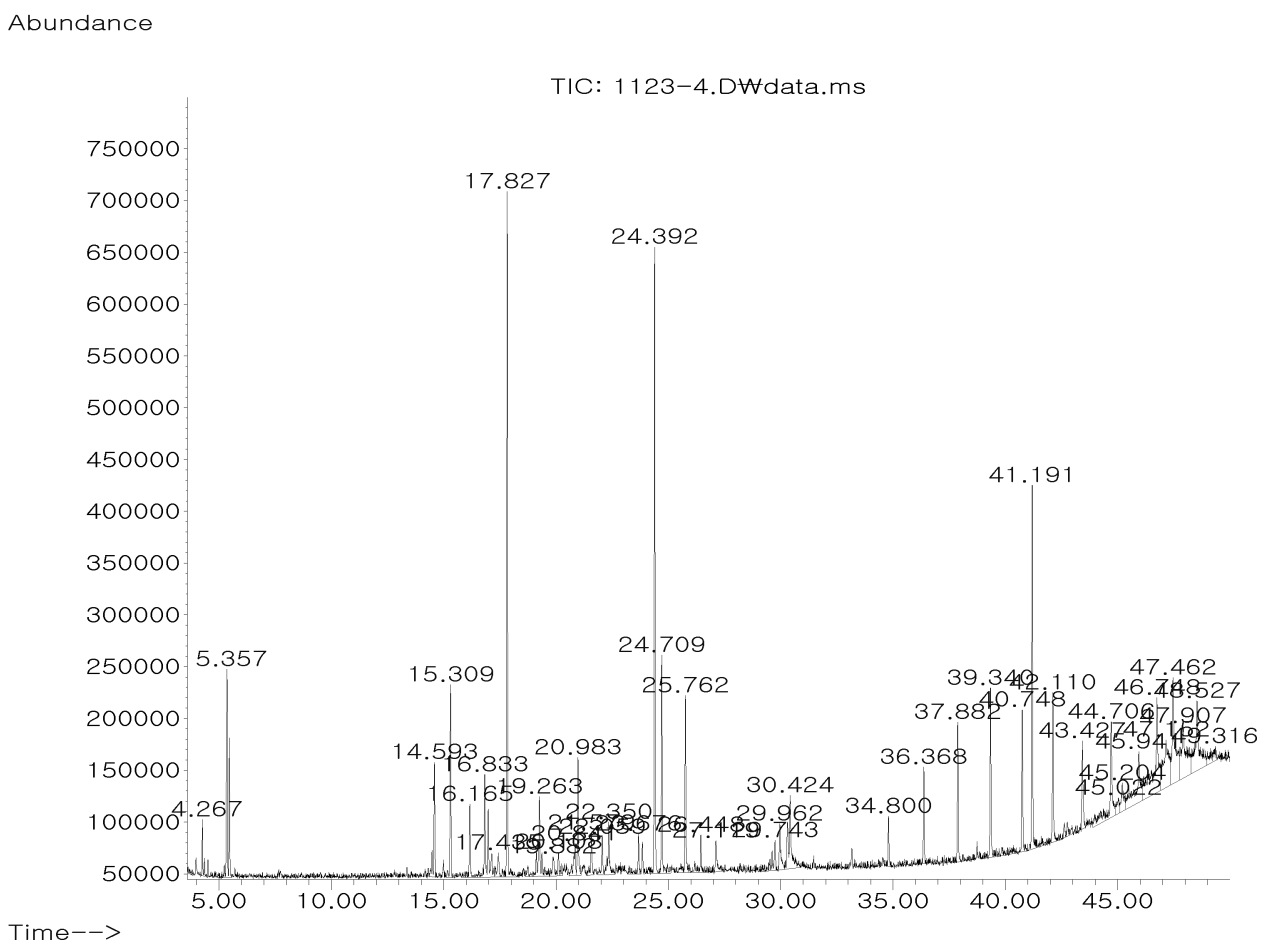

Fig. 5. Total ion chromatogram of the hexane fraction of the leaves of Ligularia stenocephala detected by GC-MS. 


\section{References}

1. Arashiki, N., Kimata, N., Manno, S., Mohandas, N. and Takakuwa, Y. 2013. Membrane peroxidation and methemoglobin formation are both necessary for band 3 clustering: mechanistic insights into human erythrocyte senescence. Biochemistry 52, 5760-5769.

2. Blois, M. S. 1958. Antioxidant determinations by the use of a stable free radical. Nature 181, 1199-1200.

3. Gotoh, N. and Niki, E. 1992. Rates ofinteractions ofsuperoxide with vitamin $\mathrm{E}$, vitamin $\mathrm{C}$ and related compounds as measured by chemiluminescence. Biochim Biophys Acta 1115, 201-207.

4. Kim, K. H., Kim, N. Y., Kim, S. H., Han, I. A. and Yook, H. S. 2012. Study on antioxidant effects of fractional extracts from Ligularia stenocephala leaves. J Korean Soc Food Sci Nutr 41, 1220-1225.

5. Kim, Y. D. and Yang, W. M. 1986. Studies on the components of wild vegetables in Korea. J Korean Soc Food Sci Nutr $15,10-16$.

6. Lee, B. I., Nugroho, A., Bachri, M. S., Choi, J. W., Lee, K. R., Choi, J. S., Kim, W. B., Lee, K. T., Lee, J. D. and Park, H. J. 2010. Anti-ulcerogenic effect and HPLC analysis of the caffeoylquinic acid-rich extract from Ligularia stenocephala. Biol Pharm Bull 33, 493-497.

7. Lee, D. K., Kim, J. K., Kim, J. S., Park, K. J., Cha, D. S. and Jeon, H. 2012. Inhibitory effect of Ligularia stenocephala on the cancer metastasis. Nat Prod Sci 18, 89-96.

8. Lu, G., Yan, F. and Li, W. 2007. Study on chemical constituents from Ligularia stenocephala. Xinxiang Yixueyuan Xuebao 24, 9-11.

9. Marx, J. L. 1987. Oxygen free radicals linked to many diseases. Science 235, 529-531.

10. Murae, T., Tanahashi, Y. and Takahashi, T. 1968. 5,6-Dimethoxy-2-isopropenylbenzofuran from Ligularia stenocephala. Tetrahedron 24, 2177-2181.

11. Nazari-Serenjeh, F., Rezayof, A. and Zarrindast, M. R. 2011. Functional correlation between GABAergic and dopaminergic systems of dorsal hippocampus and ventral tegmental area in passive avoidance learning in rats. Neuroscience 196, 104-114.
12. Nugroho, A., Bachri, M. S., Choi, J. W., Choi, J. S., Kim, W. B., Lee, B. I., Kim, J. D. and Park, H. J. 2010. The inhibitory effect of the caffeoylquinic acid-rich extract of Ligularia stenocephala leaves on obesity in the high fat diet-induced rat. Nat Prod Sci 16, 89-87.

13. Ohkawa, H., Ohishi, N. and Yagi, K. 1979. Assay for lipid peroxide in animal tissues by thiobarbituric acid reaction. Anal Biochem 95, 351-358.

14. Tota, S., Nath, C., Najmi, A. K., Shukla, R. and Hanif, K. 2012. Inhibition of central angiotensin converting enzyme ameliorates scopolamine induced memory impairment in mice: Role of cholinergic neurotransmission, cerebral blood flow and brain energy metabolism. Behav Brain Res 232, 66-76.

15. Toyoda, K., Yaoita, Y. and Kikuchi, M. 2005. Three new dimeric benzofuran derivatives from the roots of Ligularia stenocephala MATSUM. et KOIDZ. Chem Pharm Bull 53, 1555-1558.

16. Toyoda, K., Yaoita, Y. and Kikuchi, M. 2006. Constituents of the leaves and roots of Ligularia stenocephala MATSUM. et KOIDZ. J Nat Med 60, 329-330.

17. Yan, F. L., Wang, A. and Jia, Z. J. 2004. New phenol derivatives from Ligularia stenocephala. J Chem Res 742-743.

18. Yan, F. L., Wang, A. X. and Jia, Z. J. 2004. Benzofuran derivatives from Ligularia stenocephala. J Chin Chem Soc (Taipei, Taiwan) 51, 863-868.

19. Yan, F. L., Wang, A. X. and Jia, Z. J. 2004. Two new benzofuran derivatives from Ligularia stenocephala. Chin Chem Lett 15, 423-424.

20. Yan, F. L., Wang, A. X. and Jia, Z. J. 2005. Three new polymeric isopropenyl benzofurans from Ligularia stenocephala. Pharmazie 60, 155-159.

21. Yan, F. L., Wang, A. X., Jia, Z. J. and He, L. 2003. A new isopropenyl benzofuran-type tetramer from Ligularia stenocephala. Chin Chem Lett 14, 1253-1254.

22. Yaoita, Y. New sesquiterpenoids from the rhizomes of Petasites japonicus MAXIM. and the roots of Ligularia dentata HARA. Yakugaku Zasshi 132, 887-893.

23. Yoon, M. H., Cho, C. W., Lee, J. W., Kim, Y. S., An, G. H. and Lim, C. H. 2008. Antithrombotic compounds from the leaves of Ligularia stenocephala M. Nat Prod Sci 14, 62-67. 


\title{
초록 : 곤달비 잎과 뿌리의 생물 활성
}

\author{
남영주 · 이동웅* \\ (동국대학교 과학기술대학 바이오학부)
}

국내에서 식품으로 사용되고 있는 국화과 식물인 곤달비(Ligularia stenocephala) 잎과 뿌리의 생물활성을 과학적 으로 검증하기 위하여 각 추출물에 대하여 항산화 활성 및 세포독성을 in vitro에서, 간보호 효과, 알코올 해독작용 및 기억증진 효능 등을 in vivo에서 평가하였으며 잎의 독특한 향기성분을 GC-MS로 분석하였다. 지질과산화 억제 효과는 잎(20.4\% 억제율)이 뿌리 보다 좋았으며, 유해 라디칼의 일종인 superoxide anion은 뿌리에서 생성 억제효 과가 더 좋았고, $\mathrm{DPPH}$ 소거활성은 잎과 뿌리 모두 $77 \sim 79 \%$ 로 매우 뛰어났다. 사염화탄소로 유발된 급성 간독성 개선효과를 AST와 ALT 효소활성도를 지표로 확인한 결과, 잎의 ALT 억제활성이 대조군에 비해 약 $78 \%$ 정도 감소하였으며 알코올을 투여한 mouse의 혈중 알코올 농도는 잎추출물 투여시 약 $60 \%$ 가량 유의성 있게 감소되어 효과를 인정할 수 있었다. 세포독성은 뿌리에서 비교적 강하게 나타났는데, 흑색종의 경우, $\mathrm{IC}_{50}=40.14 \mathrm{mg} / \mathrm{ml}$ 이었 으며, 잎의 세포독성은 비교적 약하였다. 기억증진 효과를 동물모델을 이용한 수동회피시험법으로 평가한 결과, 잎과 뿌리 모두 scopolamine에 의해 유도된 기억력 감소를 $80 \%$ 이상 향상시킨 것으로 조사되었다. 곤달비 잎의 $n$ 헥산 추출물을 GC-MS로 분석한 결과, 독특한 향기는 주로 terpene 화합물에서 유래되는 것으로 추정되었다. 